\title{
Some Important Butterflies Captured By Junior Naturalists
}

\author{
by Ronald R. Hooper, Punnichy
}

Young people are very fond of nature. They are often thrilled by the beautiful butterflies that flit about, and sometimes they will catch one with their hat or in their hand in order to examine it more closely. Junior naturalists have often brought butterflies to me hoping that they will turn out to be a rare species but usually they prove to be something as common as the Cabbage Butterfly.

The keen eyes of junior naturalists must not be underestimated, however, for we have several species in our collection of Saskatchewan butterflies that we have not yet captured ourselves, which have been given to us from the collections of junior naturalists. The following is an account of some of them.

In the fall of 1955 a preacher's son, Wendell Marshall, of Eston, found some beautiful caterpillars feeding on dill in his mother's garden. He saved several of them in jars where they soon formed into chrysalids. The following February they hatched into charming Zelicaon Swallowtails (Papilio zelicaon Luc.). One of the chrysalids was darker than the others. It hatched into an entirely different butterfly, which turned out to be a Nitra Swallowtail (Papilio nitra kahli Cherm.). In seven summers of collecting since then I have not seen another specimen of this species.

I was enjoying the fine Junior Naturalist display of wildlife in Wascana Marsh at the Saskatchewan Museum of Natural History, in the spring of 1962, when suddenly I noticed among the butterflies a species of Copper (Lycaena) which I had never seen before. It is not in the Manitoba list of butterflies, but it is recorded from Calgary, Alberta. Alan Wade, Regina, one of the main fellows to arrange the display of Wascana Marsh wildlife, was kind enough to give me the specimen. Alan has a nice collection of butterflies in his home.

In the summer of 1961 Mike Rhodes of Moose Jaw was in some desolat: dry, prairie hills near Clay- bank when he captured a light-coloured, checkered butterfly. Later when I was looking at Mike's butterflies I saw it and knew that it was a species of checkerspot (Melitaea) that was new to me. It appears to be of a species that is taken in the Cypress Hills of Alberta, and so it may be expected in Saskatchewan, but it is surprising to see it show up as far east as Claybank.

Junior Naturalists - this proves that your collections can be of real scientific value. Here are some pointers to improve their worth.

1. Obtain a copy of A field guide to the Butterflies by Klots. It will give much helpful information concerning the mounting of butterflies.

2. Mount your specimens on insect pins. They can be purchased from J. W. Elwood Supply C., 1202 Harney Street, Omaha 2, Nebraska, or from Ward's Natural Science Est. Inc., Box 1712, Rochester 3, New York.

3. Make sure that you have a data label with each specimen, recording the place and date of capture of the butterfly.

\section{CHRISTMAS CARDS AND HASTI-NOTES}

There will not be a new 1963 Christmas card, as the Society has. on hand a supply of cards from previous years. This was decided at the business meeting of the Society, June 15, when it was agreed that we should reduce stock before ordering another cord.

However, the following cards are available from The Blue Jay, Box 1121 , Regina,

CHRISTMAS CARDS: Yellow-headed Blackbird (1.00); Downy Woodpecker (1.00); Bohemian Waxwing (1.00); Boggy Creek (.75); Snowy Owl (.50).

HASTI-NOTES: Downy Woodpecker (1.00): Yellow-headed Blackbird (1.00); Sharp-tailed Grouse (1.00); Sunflower silkscreens (1.25).

Flease indicate second choice, as some 'cards are in short supply. Note also that cards must now be ordered from Blue Jay, Box 1121 , the Shop having been taken over by the Museum by arrangement with the S.N.H.S. this spring. 